\title{
Innovativeness and Competitiveness in Creative Industries: the Case of SMEs in Maros Regency
}

\author{
Narto Irawan Otoluwa *, Ibriati Kartika Alimuddin *, Nur Alamzah **, Mursalim Nohong** \\ * Sekolah Tinggi Ilmu Manajemen, Yayasan Perguruan Islam Maros \\ ** Faculty of Economics and Business, Universitas Hasanuddin, Makassar
}

\begin{abstract}
The purpose of study was to explain the effect of entrepreneurship orientation and innovation in improving the performance and competitiveness of creative industries in Maros Regency. The primary data used in this study were collected by using questionnaires. The data is then processed in the form of descriptive statistics and inferential statistics. Based on the analysis, it is found that the orientation of entrepreneurship which is reflected by the activities of research and development activities, technological leadership, and innovation will be able to improve the performance and competitiveness of creative industry. Performance as measured by the company's ability to increase sales will be able to create competitiveness. The study also found an insignificant effect between innovation with competitiveness and performance with competitiveness.
\end{abstract}

Keywords: Entrepreneurship orientation, innovation, performance, competitiveness

\section{Introduction}

Small and medium enterprises are the strategic sector in several countries (Hunjra, 2011). This sector, for entrepreneurs, has been one source of income and contributed to labor absorption. Indonesia is one of the countries with a very increasing growth rate of small and medium enterprises each year. In 2014, it is found around 57,8 million entrepreneurs classified within small and medium enterprises and it is estimated to increase in the next few years. It is approximately $57-60 \%$ of Gross Domestic Product (PDB) from small and medium enterprises with approximately $97 \%$ of the labor absorption among overall national labor (Bank of Indonesia, 2015), while approximately $88,8-99,9 \%$ of entrepreneurs within small and medium enterprises at the ASEAN level.
The positive development of small and medium enterprises does not guarantee the sector from a number of problems. The professionalism of businessman in managing business and capital asset is often the significant factors which affect the competitiveness of a business. Competitiveness is a productivity related to the output which is produced by the labor (Porter, 1990). In addition to that, competitiveness is a concept referred to the capability of a company in competing with other companies to produce the value. In creating competitiveness, the company should implement the production of value strategy which cannot be implemented by the competitors (Barney, 1991). Moreover, competitiveness or competing excellence is the capability of an organization to operate or handle the activities in a different way and it cannot be implemented by the 
competitors (Kotler, 2000). It needs a proper strategy for optimizing the performance of the labor towards the activities conducted. However, there is no indicator used to measure competitiveness that is indeed very difficult to be measured (Markovics, 2005). Competitiveness can be produced and increased through the proper implementation of competing strategy which one of them is an optimal management of the company resources. The precision of a strategy can only be obtained if the company is able to adapt to changes in the environment and its internal setting. The proper strategy is able to create performance and source of producing value for a company. In the viewpoint of strategy, competitiveness of small and medium enterprises is affected by (1) internal factors of a company; 2) external setting; 3) effect of the entrepreneurs. In addition, competitiveness of a company is also determined by managerial capability, capital sufficiency, a system of organization and adaptive management (based on business needs), technology compatibility, information availability, and strategic inputs availability, such as energy and materials.

Entrepreneurial orientation (orientation of entrepreneurship) is one of the key successes of a company (Miller, 1983) and classified into three types, those are innovativeness, productiveness, and risk taker. In accordance with the description above, the hypothesis can be compiled as follows:

1. Entrepreneurial orientation has a positive and significant effect on performance and competitiveness.

2. Innovation has a positive and significant effect on performance and competitiveness.

According to Nia Angraini (2014), it is found an effect of performance towards competing for excellence in the industry of beauty salon and spa in Pekanbaru. The result of the research shows that the higher the performance of a business, the higher the competitiveness of a business. This result is also found on Marques and
Ferreira (2009). It leads us to the third hypothesis as follows:

3. Performance has a positive and
$\begin{aligned} & \text { significant } \\ & \text { competitiveness. }\end{aligned}$

\section{Method}

This research is causality which described the relation of entrepreneurial orientation, innovation, and competitiveness of small and medium enterprises in Maros Regency. Entrepreneurial orientation and innovation are dependent variables, while performance and competitiveness are independent. The primary data were collected from interview using questionnaire with samples as amount 110 entrepreneurs of small and medium enterprises. Descriptive statistics analysis was used to describe the variables of research, while interferential statistical analysis with Structural Equation Modeling (SEM) variance-based was used for a causal relation between variables which is known as Partial Least Square (PLS) method.

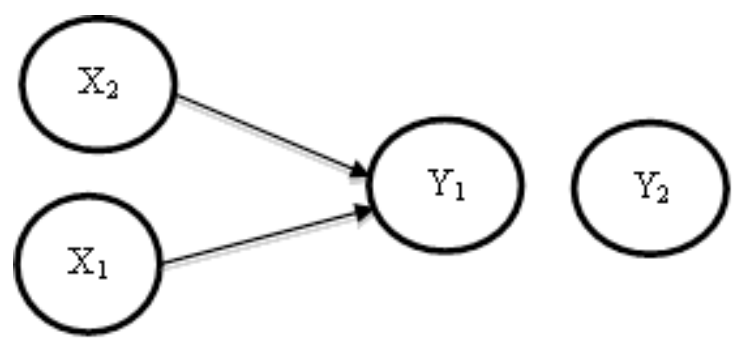

Figure 1 Research Model

$\mathrm{X} 1=$ Innovation
$\mathrm{X} 2=$ Entrepreneurial orientation
$\mathrm{Y} 1=$ Performance
$\mathrm{Y} 2=$ Competitiveness




\section{Findings and Discussion}

\section{Variable Description}

Entrepreneurial orientation variable is measured by six reflective indicators with outer loading value and p-value as in Table 1. Of the six indicators of Entrepreneurial orientation variables, the first indicator (X1.1; activity of research and development, technological leadership, and innovation) has the highest factor loading value which is the most dominant indicators of measuring the variables of Entrepreneurial orientation.

It can be concluded that the highest entrepreneurial orientation is reflected by the research and development activities, technological leadership, and innovation.

Tabel 1 The Results of Indicator Tests on Entrepreneurial Orientation Variables (X1)

\begin{tabular}{|c|c|c|c|}
\hline Variable & Indicator & $\begin{array}{c}\text { Outer } \\
\text { Loading }\end{array}$ & $\begin{array}{c}\text { p- } \\
\text { value }\end{array}$ \\
\hline \multirow{3}{*}{$\begin{array}{c}\text { Entrepre- } \\
\text { neurial } \\
\text { orientation } \\
\left(X_{1}\right)\end{array}$} & $\mathrm{X}_{1.1}$ & 0.779 & 0.000 \\
\cline { 2 - 4 } & $\mathrm{X}_{1.2}$ & 0.539 & 0.000 \\
\cline { 2 - 4 } & $\mathrm{X}_{1.4}$ & 0.636 & 0.000 \\
\cline { 2 - 4 } & $\mathrm{X}_{1.5}$ & 0.658 & 0.000 \\
\cline { 2 - 4 } & $\mathrm{X}_{1.6}$ & 0.635 & 0.000 \\
\hline
\end{tabular}

Source: Primary data processed, 2017

The second variable in this study is the innovation measured by five reflective indicators. The results of loading factor indicators of Innovation variables can be seen in Table 2 as follows:
Tabel 2 Result of Indicators Tests on Innovation Variable (X2)

\begin{tabular}{|c|c|c|c|}
\hline Variable & $\begin{array}{c}\text { Indicat } \\
\text { or }\end{array}$ & $\begin{array}{c}\text { Outer } \\
\text { Loading }\end{array}$ & $\begin{array}{c}\text { p- } \\
\text { value }\end{array}$ \\
\hline \multirow{3}{*}{$\begin{array}{c}\text { Innovation } \\
\left(\mathrm{X}_{2}\right)\end{array}$} & $\mathrm{X}_{2.1}$ & 0.680 & 0.000 \\
\cline { 2 - 4 } & $\mathrm{X}_{2.2}$ & 0.639 & 0.000 \\
\cline { 2 - 4 } & $\mathrm{X}_{2.3}$ & 0.777 & 0.000 \\
\cline { 2 - 4 } & $\mathrm{X}_{2.4}$ & 0.661 & 0.000 \\
\cline { 2 - 4 } & $\mathrm{X}_{2.5}$ & 0.625 & 0.000 \\
\hline
\end{tabular}

Source: Primary data processed, 2017

By those five indicators of Innovation variables, the third indicator (X2.3) has the highest loading factor value in which the most dominant indicator of measuring Innovation variables. This shows that the ability to build a business network becomes the highest indicator to establish creative industry innovation.

The regional performance variable is measured by two reflective indicators. Results of loading factor indicators of the regional Performance variables can be seen in Table 3 as follows:

Tabel 3 The Results of Indicator Test on Performance Variables (Y1)

\begin{tabular}{|c|c|c|c|}
\hline Variable & $\begin{array}{c}\text { Indica } \\
\text { tor }\end{array}$ & $\begin{array}{c}\text { Outer } \\
\text { Loading }\end{array}$ & $\begin{array}{c}\text { p- } \\
\text { value }\end{array}$ \\
\hline \multirow{3}{*}{$\begin{array}{c}\text { Performance } \\
\left(Y_{1}\right)\end{array}$} & $\mathrm{Y}_{1.1}$ & 0.779 & 0.000 \\
\cline { 2 - 4 } & $\mathrm{Y}_{1.2}$ & 0.675 & 0.000 \\
\cline { 2 - 4 } & $\mathrm{Y}_{1.3}$ & 0.764 & 0.000 \\
\cline { 2 - 4 } & $\mathrm{Y}_{1.4}$ & 0.562 & 0.000 \\
\cline { 2 - 4 } & $\mathrm{Y}_{1.5}$ & 0.665 & 0.000 \\
\hline
\end{tabular}

Source: Primary data processed, 2017

By those five indicators of Performance variables, the first indicator (Y1.1) is the highest loading factor value which is the most dominant indicator of measuring Performance variables. This shows that the high-performance variable defined by the 
Y1.1 indicator. In other words, the performance of the creative industry (UMKM) is high if it has a sales growth

The regional Competitiveness variables are measured by six reflective indicators. The result of loading factor of indicators of regional competitiveness variable can be seen in Table 4 as follows:

Tabel 4 Results of Indicator Test on Competitiveness Variables (Y2)

\begin{tabular}{|c|c|c|c|}
\hline Variable & Indicators & $\begin{array}{c}\text { Outer } \\
\text { Loading }\end{array}$ & $\begin{array}{c}\text { p- } \\
\text { value }\end{array}$ \\
\hline \multirow{4}{*}{$\begin{array}{c}\text { Competiti } \\
\text { veness } \\
\left(\mathrm{Y}_{2}\right)\end{array}$} & $\mathrm{Y}_{2.1}$ & 0.670 & 0.000 \\
\cline { 2 - 4 } & $\mathrm{Y}_{2.2}$ & 0.644 & 0.000 \\
\cline { 2 - 4 } & $\mathrm{Y}_{2.3}$ & 0.589 & 0.000 \\
\cline { 2 - 4 } & $\mathrm{Y}_{2.4}$ & 0.670 & 0.000 \\
\cline { 2 - 4 } & $\mathrm{Y}_{2.5}$ & 0.684 & 0.000 \\
\hline
\end{tabular}

Source: Primary data processed, 2017

Of the four indicators of Competitiveness variables, the fifth indicator (Y2.5) has the highest loading factor value in which the most dominant indicator measuring Competitiveness variable. Based on the competitiveness indicators in this study, the performance will form a capable company of producing quality products.

\section{Hypothesis testing}

Inner model testing (structural model) essentially tests the hypothesis in the study. Hypothesis testing is done by t-test (T-Statistic) on each partial direct effect. The results of complete analysis can be seen in Table 5.

The result of SEM analysis testing on the direct effect testing between Entrepreneurial orientation and performance obtained inner loading coefficient value of 0.523 , with $p$-value of o.ooo. Based on these values, it can be concluded that there is a significant direct effect of Entrepreneurial orientation towards performance. In other words, the higher the entrepreneurship orientation, the higher the performance of creative industries. Associated with indicators of each variable, it shows that the more routine or many activities of research and development, technological leadership, and innovation undergone, the growth of creative industry sales will be higher. This result is in line with Yaseen Zeebaree study (2017) which explains the direct effect on Entrepreneurial orientation and performance.

In the testing of the direct effect between the Entrepreneurial orientation and competitiveness, the value of inner loading coefficient is 0.394 , with p-value equal to 0.000 . Based on the results of the analysis there is a significant direct effect of Entrepreneurial orientation towards competitiveness. It means that the competitiveness of creative industries can be achieved if the entrepreneurial orientation is the concern of every business actor. In terms of variable indicators, it can be concluded that creative industries will be able to produce quality products when conducting research and development activities, technological leadership, and innovation effectively.

In the testing of the direct effect between Innovation and performance, the inner coefficient value of 0.069 with pvalue is 0.472 . Due to $p$-value $>0.05$, it can be concluded that there is a non-significant direct effect on Innovation and Performance. Therefore, high/low Innovation will not result in changing the higher/lower Performance. In other words, the ability to build a business network by a creative industry does not significantly encourage sales growth. Therefore, the creative industry in building business networks with other parties should be able to impact on sales.

In the testing of the direct effect of Innovation towards Competitiveness, it obtained the value of inner loading coefficient of 0.116 with p-value of 0.121 . Based on these values, it can be concluded that there is a non-significant direct effect between Innovation and Competitiveness. 
Tabel 5 The Result of hypothesis testing

\begin{tabular}{|l|c|c|c|}
\hline \multicolumn{1}{|c|}{ Correlation } & $\begin{array}{c}\text { coefficient } \\
\text { path }\end{array}$ & $p$-value & Information \\
\hline Entrepreneurial orientation $\rightarrow$ Performance & 0.523 & 0.000 & Significant \\
\hline $\begin{array}{l}\text { Entrepreneurial orientation } \rightarrow \\
\text { Competitiveness }\end{array}$ & 0.394 & 0.000 & Significant \\
\hline Innovation $\rightarrow$ Performance & 0.069 & 0.472 & Non-significant \\
\hline Innovation $\rightarrow$ Competitiveness & 0.116 & 0.121 & Non-significant \\
\hline Performance $\rightarrow$ Competitiveness & 0.390 & 0.000 & Non-significant \\
\hline
\end{tabular}

Source: Primary data processed, 2017

${ }^{*}$ Significant on $\alpha=5 \%$

As a result, the higher / lower Innovation will not result in changes the higher / lower the competitiveness.

In testing of the direct effect between performance and competitiveness, the value of inner loading coefficient is 0.390 , with $\mathrm{p}$-value equal to 0.00o. Because pvalue <0.05. Based on these results, it shows a significant direct effect of performance towards competitiveness. Since the inner loading coefficient is positive, the correlation is both positive. In other words, the higher the performance will result in higher competitiveness. 


\section{References}

Bank Indonesia. (2015). Profil Bisnis Usaha Mikro, Kecil, dan Menengah (UMKM). Kerjasama Lembaga Pengembangan Perbankan Indonesia dengan Bank Indonesia.

Barney, J. (1991). Firm resources and sustained competitive advantage. Journal of Management, Vol. 17 No. 1, pp.99-120.

Darwanto. (2013). Peningkatan daya saing UMKM berbasis inovasi dan kreativitas (strategi penguatan property right terhadap inovasi dan kreativitas), Jurnal Bisnis dan Ekonomi (JBE), Vol. 20, No. 2, 142 149

Hunjra,.A. (2011). Determinants of Business Success of Small and Medium Enterprises. International Journal of Business and Social Science Vol. $\mathrm{Nr}$ 20; November 2011

Kotler, Philip. (2000). Marketing Management: Edisi Milenium, International Edition. Prentice Hall International, Inc, New Jersey

Kraja (Borici), Ylvije., Osmani, Elez. (2013). Competitive advantage and its impact in small and medium enterprises (SMES) (Case of Albania). European Scientific Journal, Vol.9, No.16, $76-85$

Markovics, Klára. (2005). Competitiveness of Domestic Small and Medium Enterprises in the European Union. European Integration Studies, Miskolc, Volume 4. Number 1. 13-24.

Marques, Carla Susana dan Ferreira, João. (2009). SME Innovative Capacity, Competitive Advantage and Performance in a 'Traditional' Industrial Region of Portugal. Journal of Technology Management \& Innovation, Volume 4, Issue 4

Nia Anggraini, Marnis dan Samsir. 2014. Strategi orientasi pasar, inovasi, dan orientasi pembelajaran pengaruhnya terhadap kinerja usaha serta dampaknya terhadap keunggulan bersaing (Studi pada industri jasa salon kecantikan dan spa di kota pekanbaru), Jurnal Sosial Ekonomi Pembangunan, No.12, 295-311

Parnell, J.A. 2006. "Generic strategies after two decades: a reconceptualization of competitive strategy", Management Decision, Vol. 44 No. 8, pp. 1139-154.

Parnell, J.A. 2011, "Strategic capabilities, competitive strategy, and performance among retailers in Argentina, Peru and the United States", Management Decision, Vol. 49 No. 1, pp. 130-55.

Porter, M.E. 1980. Competitive Strategy, The Free Press, New York, NY.

Ritala, P. and Ellonen, H.K. 2010. "Competitive advantage in interfirm cooperation: old and new explanations", Competitiveness Review: An International Business Journal, Vol. 20 No. 5, pp. 367-83.

Sirivanh, Thongvanh., Sukkabot, Sasiwemon., and Sateeraroj, Meta. (2014). The Effect of Entrepreneurial Orientation and Competitive Advantage on SMEs' Growth: A Structural Equation Modeling Study, International Journal of Business and Social Science, Vol. 5, No. 6(1), 189 914

YaseenZeebaree, Mohammed R., Siron, Rusinah Bt. (2017). The Impact of Entrepreneurial Orientation on Competitive Advantage Moderated by Financing Support in SMEs. International Review of Management and Marketing, 7(1), 43-52.

Zulkifli, R. Mohamad., and Rosli, M. Mohd. (2013). Entrepreneurial Orientation and Business Success of Malay Entrepreneurs: Religiosity as Moderator. International Journal of Humanities and Social Science, Vol. 3 No. 10, $264-275$ 